\title{
The Reserpine-Treated Rat as an Experimental Animal Model for Cystic Fibrosis: Abnormal Cl Transport in Pancreatic Acinar Cells
}

\author{
J. RICARDO MARTINEZ AND A. M. MARTINEZ \\ Departments of Child Health and Physiology, University of Missouri School of Medicine, \\ Columbia, Missouri 65212
}

\begin{abstract}
Pancreatic acini of control and reserpinetreated rats were incubated with the isotopic tracer ${ }^{36} \mathrm{Cl}$ to compare $\mathrm{Cl}$ accumulation in the absence and presence of secretagogues and transport inhibitors. Two phases of $\mathrm{Cl}$ accumulation were ascertained in resting control cells: an initial rate (0-5 min) and a steady state level (10-30 min) of accumulation. Both phases were enhanced by acetylcholine $(1 \mu \mathrm{M})$ and caerulein $(10 \mathrm{nM})$, but not by $10 \mathrm{nM}$ vasointestinal peptide or $10 \mu \mathrm{M}$ forskolin. Exposure to 1 mM DIDS (4,4' -diisothiocyano-2,2'-stilbene disulfonic acid) inhibited both phases of $\mathrm{Cl}$ accumulation, whereas exposure to $1 \mathrm{mM}$ amiloride had a delayed effect on the initial rate and reduced the steady state phase in both resting (unstimulated) or acetylcholine-stimulated cells. Furosemide (1 $\mathrm{mM}$ ) had no effect on $\mathrm{Cl}$ accumulation when added to the cells just before tracer, but reduced it when added $10 \mathrm{~min}$ before. Neither the initial phase nor the steady state level of $\mathrm{Cl}$ accumulation were enhanced by acetylcholine in acini of reserpine-treated rats and the effect of DIDS on the initial phase was smaller than in control cells. Continued exposure to this inhibitor resulted, furthermore, in a significantly larger steady state $\mathrm{Cl}$ content. The inhibitory effects of amiloride and of a 10-min preincubation with furosemide were similar to those observed in control cells. These results suggest that $\mathrm{Cl}$ accumulates in rat pancreatic acini by way of DIDS-sensitive mechanisms that are activated by $\mathrm{Ca}^{2+}$-mediated, but not by cAMP-mediated, secretagogues. These mechanisms are altered in acini of reserpine-treated rats. Those responsible for the early (initial) phase are made insensitive to secretagogues but retain some sensitivity to DIDS. Mechanisms responsible for the maintenance of the steady state level are also altered as suggested by the paradoxical effect of DIDS. As this inhibitor blocks $\mathrm{Cl}$ conductances and $\mathrm{Cl} /$ $\mathrm{HCO}_{3}$ exchange, either or both of these transport mechanisms may be altered after chronic reserpine. This alteration can explain the reduced in vivo pancreatic fluid secretion observed in the treated animals, as pancreatic fluid secretion is $\mathrm{Cl}$-dependent in the rat. The reserpine-treated rat is an experimental model of cystic fibrosis and a similar defect in $\mathrm{Cl}$ transport may also underlie the reduced pancreatic fluid secretion observed in this disease. A generalized defect in $\mathrm{Cl}$ transport may be present in exocrine cells of CF patients and of the animal model, involving alterations in the interaction of membrane transport mechanisms with regulatory molecules activated by tissue-specific second messengers. (Pediatr Res 24: 427-432, 1988)
\end{abstract}

Received October 14, 1987; accepted May 27, 1988

Address correspondence and reprint requests to J. Ricardo Martinez, M.D. Department of Child Health, University of Missouri School of Medicine, Columbia MO 65212.

\begin{abstract}
Abbreviations
CF, cystic fibrosis

DIDS, 4, 4' -diisothiocyano-2,2'-stilbene disulfonic acid VIP, vasointestinal peptide
\end{abstract}

Rats treated for several days with pharmacologic doses of reserpine develop exocrine gland abnormalities resembling those of $\mathrm{CF}$, including structural changes compatible with accumulation of secretory material and alterations in fluid, electrolyte, and protein of glycoprotein secretion (1-10). In the pancreas, there are reductions in the volume of pancreatic juice, in $\mathrm{Cl}$ and $\mathrm{HCO}_{3}$ outputs and in the secretion of amylase, whereas the secretion of proteases is increased $(4,7,8)$. A reduced pancreatic fluid secretory response is observed after stimulation with cholinergic agents and peptide hormones, which are thought to act primarily on pancreatic acinar cells in the rat (11-15), and which stimulate secretion via $\mathrm{Cl}$ transport mechanisms $(12,14,15)$. In view of recent evidence that defective $\mathrm{Cl}$ transport is a basic cellular disturbance in two exocrine tissues of cystic fibrosis patients (16-18), we hypothesized that a defect in $\mathrm{Cl}$ transport may also be present in pancreatic acinar cells of the reserpinetreated rat. This view is supported by observations that transepithelial $\mathrm{Cl}$ transport is abnormal in isolated salivary acinar cells (19) and in isolated, perfused tracheas (20) of this experimental model. To test if $\mathrm{Cl}$ transport is likewise altered in pancreatic cells, we compared $\mathrm{Cl}$ uptake in acini of control and reserpinetreated rats. The isotopic tracer ${ }^{36} \mathrm{Cl}$ was used to measure $\mathrm{Cl}$ accumulation in the absence and in the presence of secretagogues and of transport inhibitors in the two types of acinar cells.

\section{MATERIALS AND METHODS}

Adult male rats of the Sprague Dawley strain were used. Some were given 7 daily intraperitoneal injections of reserpine in a dose of $0.5 \mathrm{mg} / \mathrm{kg}$ body weight, as previously described (2-10). The pancreas was removed under pentobarbital anesthesia (6-8 $\mathrm{mg} / 100 \mathrm{~g}$ body weight, intraperitoneally) from both untreated controls and drug-treated animals and was rapidly cut into small fragments that were incubated in a dispersion solution of the following composition (in mmol/liter): $\mathrm{NaCl}, 118 ; \mathrm{NaHCO}_{3}, 25$; $\mathrm{KCl}, 4.7 ; \mathrm{NaH}_{2} \mathrm{PO}_{4}, 1 ; \mathrm{MgCl}_{2}, 1.1 ; \mathrm{CaCl}_{2}, 1.28 ;$ and glucose, $15 ;$ $\mathrm{pH}=7.4$. The medium also contained a basic amino acid mixture (GIBCO, Grand Island, NY), $2 \mathrm{U} / \mathrm{mg}$ wet tissue of collagenase (Sigma Chemical Co., St. Louis, MO), $10 \mathrm{U} / \mathrm{mg}$ wet tissue of hyaluronidase (Sigma), $0.1 \mathrm{mg} / \mathrm{ml}$ of trypsin inhibitor, and $0.2 \%$ albumin and was kept at $37^{\circ} \mathrm{C}$ and continuously bubbled with a $95 \% \mathrm{O}_{2}-5 \% \mathrm{CO}_{2}$ gas mixture. The fragments were incubated in this solution for $15 \mathrm{~min}$ and then resuspended 
in fresh dispersion medium containing the enzymes and incubated for an additional $60 \mathrm{~min}$. The fragments were mechanically dispersed by passage through plastic pipettes at 40,50 , and 60 min, filtered through nylon mesh, resuspended in fresh medium and layered over $4 \%$ albumin. The resulting suspension was centrifuged, the supernatant was discarded, and the pellet was resuspended in fresh medium and divided into flasks for equilibration in the final incubation medium for 10-15 min.

To measure $\mathrm{Cl}$ accumulation, $1 \mu \mathrm{Ci} / \mathrm{ml}$ of ${ }^{36} \mathrm{Cl}$ (as the $\mathrm{NaCl}$ salt, ICN Chemicals, Irvine, CA, sp. act. $18.1 \mathrm{mCi} / \mathrm{g}$ ) was added to each flask in the absence or in the presence of test substances and samples of the suspension $(200 \mu \mathrm{l})$ were subsequently removed in duplicate at timed intervals. The cells were separated from the medium by suction filtration through nucleopore filters ( $25 \mathrm{~mm}$ diameter, $3 \mu \mathrm{M}$ pore size), and the filters were then washed with $10 \mathrm{ml}$ of ice-cold, isotope-free medium. The radioactivity remaining was measured by liquid scintillation spectrometry in a Beckman 3801 counter. The protein content of appropriate aliquots $(0.5 \mathrm{ml})$ of the various cell suspensions was measured by the Lowry method (21) after sonication of the pellets. Changes in the tracer content of the cells was evaluated in the absence of test substances and in the presence of acetylcholine, caerulein, VIP, and forskolin. The effects of the following transport inhibitors on $\mathrm{Cl}$ accumulation were also investigated: amiloride, DIDS, and fuorsemide. The inhibitors were added to the suspensions either at time zero (i.e. just before secretagogue and tracer) or $10 \mathrm{~min}$ before.

Values for counts in the various samples removed over the course of the experiments, for total counts added, and for the concentration of non-isotopic $\mathrm{Cl}$ in the incubation medium $(\mu \mathrm{mol} / \mathrm{ml})$ were used to calculate a "cold" $\mathrm{Cl}$ content of the cells at the different time points according to the formula

$$
\frac{[\mathrm{Cl}]_{\circ}}{\text { total } \mathrm{cpm}} \times \frac{\mathrm{cpm} \text { sample }}{\mathrm{mg} / \mathrm{ml} \text { protein }} \times 1000=\mathrm{nmol} / \mathrm{mg} \text { protein }
$$

Mean values for $\mathrm{Cl}$ content at the various times after exposure to tracer and to test substances were calculated from the data of similar experiments and compared by Student's $t$ test. Control experiments to measure basal $\mathrm{Cl}$ accumulation were performed with each series of experiments involving drugs. The data from several of these control experiments were pooled in the case of similar drug protocols to generate the graphs shown in "Results" for the two types of acinar preparation. Data for experiments with secretagogues or inhibitors refer to the specific experiments in each case.

\section{RESULTS}

Accumulation of $\mathrm{Cl}$ in absence and presence of secretagogues. A time-dependent accumulation of ${ }^{36} \mathrm{Cl}$ was observed in pancreatic acini of control (untreated) rats not exposed to either secretagogues or transport inhibitors. The values of $\mathrm{Cl}$ content calculated as described above from the radiotracer data are shown in Figure 1. The tracer content (and the calculated $\mathrm{Cl}$ content) of the cells rose rapidly upon addition of tracer and was $79 \pm 5$ $\mathrm{nmol} / \mathrm{mg}$ protein after $1 \mathrm{~min}$ of incubation and $102 \pm 6 \mathrm{nmol} /$ $\mathrm{mg}$ protein after $3 \mathrm{~min}$ (Fig. 1). After $5 \mathrm{~min}$ of incubation, the calculated $\mathrm{Cl}$ content was $114 \pm 7 \mathrm{nmol} / \mathrm{mg}$ protein (Fig. 1). Between 10 and $30 \mathrm{~min}$, the $\mathrm{Cl}$ content varied between $119 \pm 8$ and $107 \pm 7 \mathrm{nmol} / \mathrm{mg}$ protein (Fig. 1). The mean of the values between 10 and $30 \mathrm{~min}$ of incubation was $111 \pm 4 \mathrm{nmol} / \mathrm{mg}$ protein and was considered as a steady state content. The data just described show, therefore, two components of $\mathrm{Cl}\left({ }^{36} \mathrm{Cl}\right)$ accumulation in unstimulated pancreatic acini of control rats: an initial rate of tracer accumulation (i.e. between 0 and 4-5 $\mathrm{min}$ ) and a steady state level (i.e. between 10 and $30 \mathrm{~min}$ ).

Figure 1 also shows the results of experiments in which control acini were exposed at time zero to either $1 \mu \mathrm{M}$ acetylcholine or to $10 \mathrm{nM}$ caerulein. Both secretagogues enhanced the initial rate

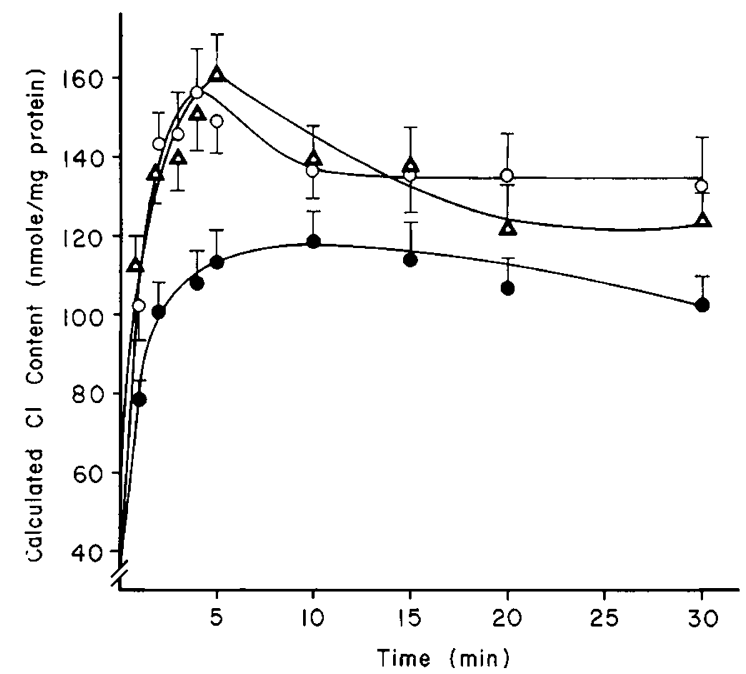

Fig. 1. Time-related changes in $\mathrm{Cl}$ content of pancreatic acini of control rats in the absence (closed circles) and in the presence of either $1 \mu \mathrm{M}$ acetylcholine (open circles) or $10 \mathrm{nM}$ caerulein (open triangles). Acini were exposed to ${ }^{36} \mathrm{Cl}$ and to secretagogue at time zero. Data shown are the means $\pm \mathrm{SE}$ for each time point from 12 control experiments (six done in parallel with the acetylcholine experiments and six with the caerulein experiments) and of six each for the two secretagogues.

of $\mathrm{Cl}$ accumulation (see below) and induced a significantly greater steady state content. In the case of acetylcholine, the $\mathrm{Cl}$ content after $1 \mathrm{~min}$ of incubation was $102 \pm 8 \mathrm{nmol} / \mathrm{mg}$ protein and, after $4 \mathrm{~min}, 157 \pm 11 \mathrm{nmol} / \mathrm{mg}$ protein. Both values were significantly higher $(p<0.01)$ than the corresponding ones observed in the absence of secretagogue (Fig. 1). The steady state $\mathrm{Cl}$ content (i.e. between 10 and $30 \mathrm{~min}$ ) in the presence of acetylcholine (135 $\pm 2 \mathrm{nmol} / \mathrm{mg}$ protein) was also significantly higher $(p=0.001)$ than under basal conditions.

Similar results were obtained with caerulein, although the effect on steady state accumulation was not as sustained as in the case of acetylcholine (Fig. 1). The $\mathrm{Cl}$ content in the presence of caerulein was $112 \pm 8 \mathrm{nmol} / \mathrm{mg}$ protein after 1 min of incubation and $161 \pm 10 \mathrm{nmol} / \mathrm{mg}$ protein after $5 \mathrm{~min}$ (Fig. 1). Both values were significantly higher $(p<0.05)$ than the corresponding basal values in the absence of stimulant. The calculated steady state $\mathrm{Cl}$ content in the presence of caerulein was $131 \pm 4$ $\mathrm{nmol} / \mathrm{mg}$ protein, which was also significantly higher $(p=0.01)$ than that of unstimulated cells.

Figure 2 shows the results of similar experiments with acini of reserpine-treated rats. The same two components of $\mathrm{Cl}$ accumulation were observed in cells not exposed to secretagogues. The $\mathrm{Cl}$ content of unstimulated cells after $1 \mathrm{~min}$ of incubation was $65 \pm 4 \mathrm{nmol} / \mathrm{mg}$ protein and, after $5 \mathrm{~min}, 96 \pm 3 \mathrm{nmol} / \mathrm{mg}$ protein (Fig. 2). Although the rate of $\mathrm{Cl}$ accumulation during the first 5 min of incubation appeared similar to that observed in control acini (see Fig. 4 below), the $\mathrm{Cl}$ content at early time points (i.e. from 1 to $5 \mathrm{~min}$ ) was significantly lower than in control acini (compare Figs. 2 and 1). The steady state $\mathrm{Cl}$ content in unstimulated acini of reserpine-treated rats was $98 \pm 2 \mathrm{nmol} /$ mg protein (Fig. 2). This was also significantly smaller $(p=0.01)$ than the steady state $\mathrm{Cl}$ content attained in control acini and shown in Figure 1.

In contrast to control acini, those of reserpine-treated animals did not show an increased $\mathrm{Cl}$ accumulation in the presence of secretagogues (Fig. 2). The $\mathrm{Cl}$ content in the presence of $1 \mu \mathrm{M}$ acetylcholine was $78 \pm 6 \mathrm{nmol} / \mathrm{mg}$ protein after 1 min of incubation and $99 \pm 6 \mathrm{nmol} / \mathrm{mg}$ protein after $5 \mathrm{~min}$ (Fig. 2). The 1 -min value was of borderline significance $(p=0.05)$ in relation to the corresponding basal but the $5 \mathrm{~min}$ value was not significantly different from the $5 \mathrm{~min}$ basal $(p=0.2)$. Similarly, steady state $\mathrm{Cl}$ content in the presence of acetylcholine was not 
different $(p=0.2)$ from that observed in its absence $(101 \pm 3$ versus $98 \pm 2 \mathrm{nmol} / \mathrm{mg}$ protein, respectively). Exposure to 10 $\mathrm{nM}$ caerulein did not significantly enhance $\mathrm{Cl}$ accumulation in the acini of reserpine-treated animals (Fig. 2). Cl content values at either the initial period $(0-5 \mathrm{~min})$ or the steady state accumulation (105 $\pm 7 \mathrm{nmol} / \mathrm{mg}$ protein) were not significantly different than those observed in the absence of caerulein (Fig. 2).

Effects of DIDS and amiloride. Acini from control and reserpine-treated rats were exposed to either $1 \mathrm{mM}$ DIDS or $1 \mathrm{mM}$ amiloride at time zero (i.e. immediately before tracer) and tracer accumulation was monitored as indicated. The results are shown in Figure 3. In control cells, DIDS inhibited both the initial phase and the steady state accumulation of $\mathrm{Cl}$. The calculated $\mathrm{Cl}$ content was significantly smaller after $1 \mathrm{~min}(42 \pm 2 \mathrm{nmol} / \mathrm{mg}$ protein, $p=0.001)$ and $5 \mathrm{~min}(85 \pm 8 \mathrm{nmol} / \mathrm{mg}$ protein, $p=$

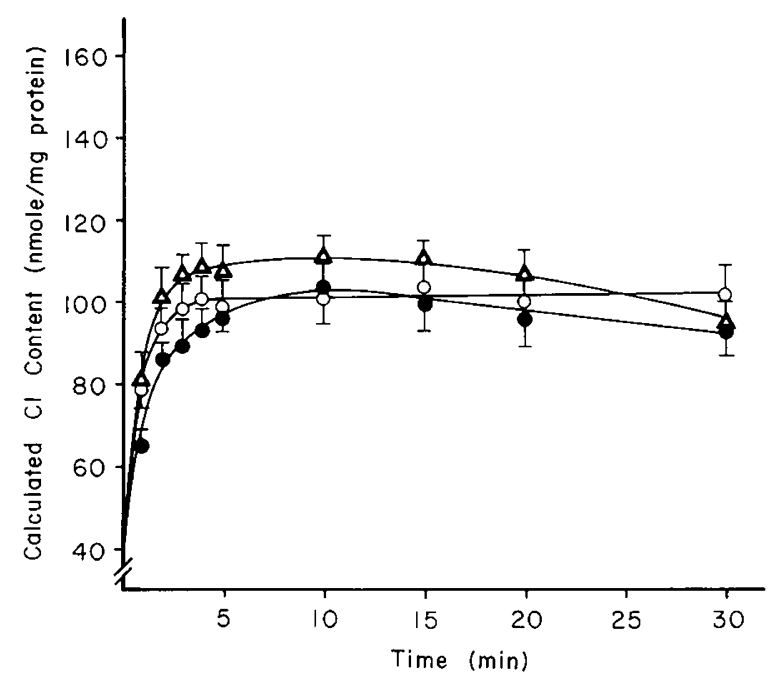

Fig. 2. Time-related changes in $\mathrm{Cl}$ content of pancreatic acini of reserpine-treated rats incubated in the absence (closed circles) and in the presence of either $1 \mu \mathrm{M}$ acetylcholine (open circles) or $10 \mathrm{nM}$ caerulein (open triangles). Protocol was similar to that of Figure 1. Data are the means \pm SE from eight control experiments (no secretagogue) and four each for the two secretagogues indicated.

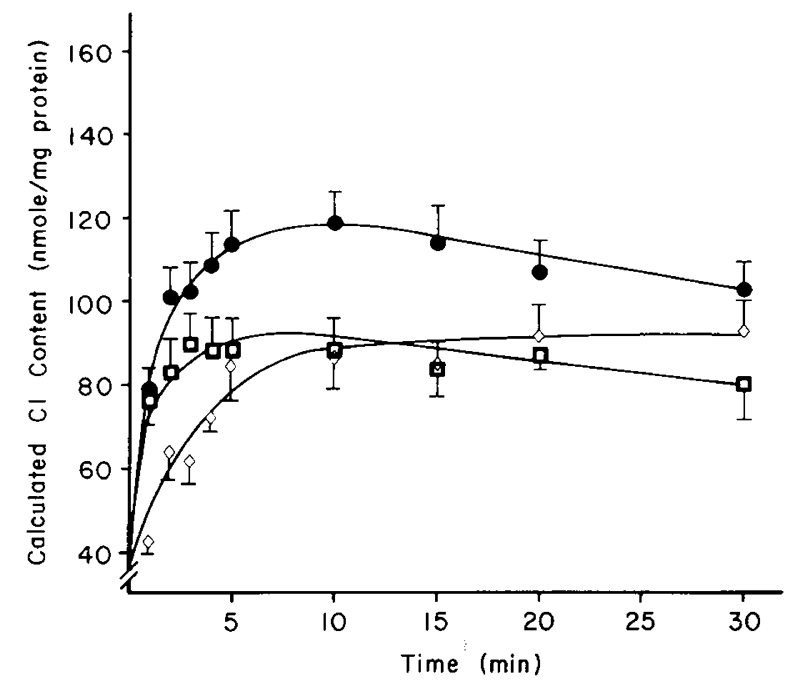

0.01) of incubation than in the absence of the inhibitor. Steady state $\mathrm{Cl}$ content was also significantly smaller $(p=0.001)$ than in cells not exposed to DIDS ( $86 \pm 2 \mathrm{nmol} / \mathrm{mg}$ protein, Fig. 3 ). The effect of amiloride on control acini was not clear cut in the first min of incubation, when the $\mathrm{Cl}$ content $(76 \pm 3 \mathrm{nmol} / \mathrm{mg}$ protein) was similar $(p=0.2)$ to that of cells not exposed to this inhibitor (Fig. 3). At $5 \mathrm{~min}$, however, the $\mathrm{Cl}$ content in the presence of amiloride $(87 \pm 4 \mathrm{nmol} / \mathrm{mg}$ protein $)$ was significantly lower $(p=0.01)$ than in unexposed cells and steady state $\mathrm{Cl}$ content was $85 \pm 2 \mathrm{nmol} / \mathrm{mg}$ protein, a value significantly lower $(p=0.001()$ than in cells not exposed to this inhibitor (Fig. 3).

DIDS also significantly reduced the initial phase of $\mathrm{Cl}$ accumulation in acini of reserpine-treated rats (Fig. 3). $\mathrm{Cl}$ content in the presence of this inhibitor was $44 \pm 3 \mathrm{nmol} / \mathrm{mg}$ protein after 2 min of incubation ( $p=0.001$ when compared to basal) (Fig. 3 ). After this initial reduction in $\mathrm{Cl}$ content, however, the $\mathrm{Cl}$ content increased significantly in the acini of reserpine-treated rats exposed to DIDS, so that $\mathrm{Cl}$ content was $137 \pm 9 \mathrm{nmol} / \mathrm{mg}$ protein at $10 \mathrm{~min}$ and reached approximately $180 \mathrm{nmol} / \mathrm{mg}$ protein between 20 and $30 \mathrm{~min}$ of incubation. This was significantly higher $(p=0.001)$ than the steady state $\mathrm{Cl}$ in cells not exposed to DIDS (Fig. 3). As in control acini, the effect of amiloride was not clear cut in the first min of incubation, when the $\mathrm{Cl}$ content $(68 \pm 7 \mathrm{nmol} / \mathrm{mg}$ protein) was not significantly different $(p=0.2)$ from that observed in the absence of this inhibitor $(65 \pm 4 \mathrm{nmol} / \mathrm{mg}$ protein, Fig. 3$)$. $\mathrm{Cl}$ content at subsequent time points was, however, significantly smaller in the presence of amiloride and steady state $\mathrm{Cl}$ content was $75 \pm 1$ $\mathrm{nmol} / \mathrm{mg}$ protein, a value significantly smaller $(p=0.001)$ than in the absence of amiloride (Fig. 3).

The data shown in Figures 1-3 for the initial phase of $\mathrm{Cl}$ accumulation were further analyzed by calculating rates of $\mathrm{Cl}$ accumulation between 1 and $5 \mathrm{~min}$ of incubation from the mean values shown in the figures. The reciprocals ( $1 /$ rate) of the rates at the various time points were then plotted against time and the results are shown in Figure 4. It can be seen that, in control acini, the rate of $\mathrm{Cl}$ accumulation is enhanced by acetylcholine (as suggested by the reduced 1/rate relationship), whereas DIDS reduces it (as indicated by the increased reciprocal of the rate). As indicated by the data in Figure 3, the effect of amiloride, however, is more clear in the latter part of the accumulation period (Fig. 4). In acini isolated from reserpine-treated rats, the

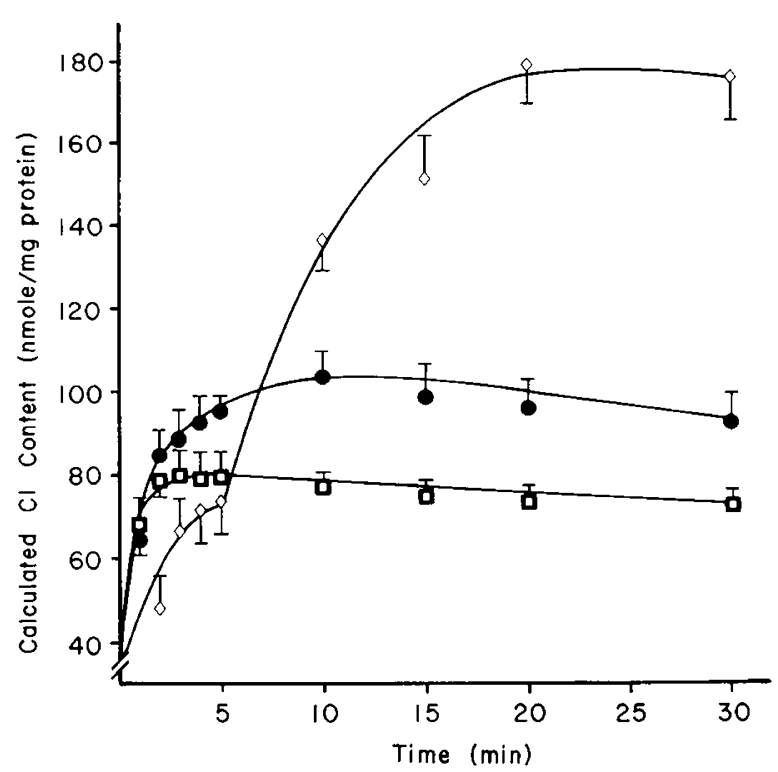

Fig. 3. Left panel, time-related changes in $\mathrm{Cl}$ content of pancreatic acini from control rats incubated in the absence (closed circles) and in the presence of either $1 \mathrm{mM}$ DIDS (open diamonds) or $1 \mathrm{mM}$ amiloride (open squares). Cells were exposed to ${ }^{36} \mathrm{Cl}$ and to test substances at time zero. Data are means \pm SE from 10 control experiments and five each for the two inhibitors. Right panel, time-related changes in acini of reserpinetreated rats incubated in the absence (closed circles) and in the presence of either $1 \mathrm{mM}$ DIDS (open diamonds) or $1 \mathrm{mM}$ amiloride (open squares). Data are the mean \pm SE of eight control experiments and four each for the two inhibitors. 
CONTROL

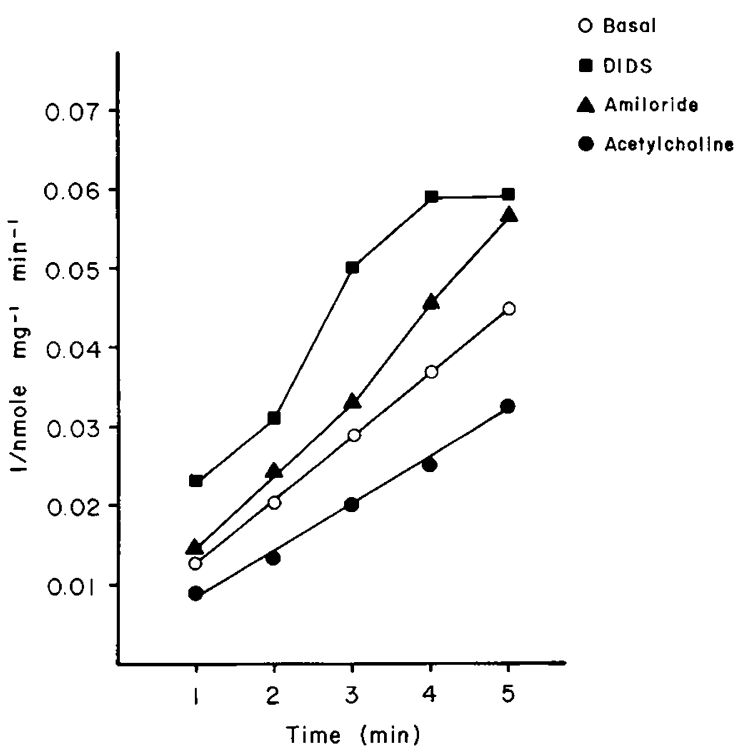

\section{RESERPINE}

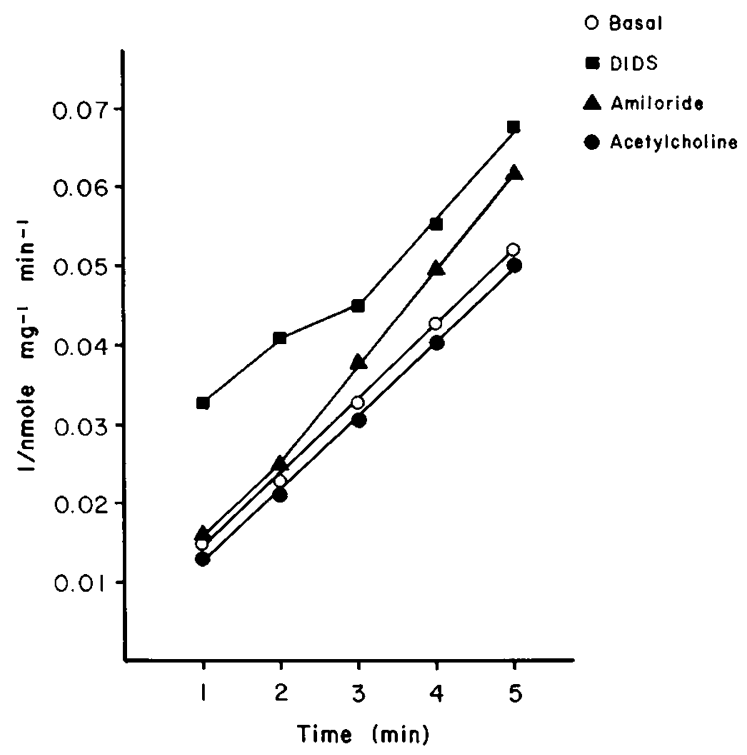

Fig. 4. Left panel, reciprocals of the rates of $\mathrm{Cl}$ accumulation (1/rate) in control acini in the absence (open circles) and presence of the test substances indicated. Data shown are derived from those shown in Figure 1 and the left panel of Figure 3. Right panel, reciprocals of the rates of $\mathrm{Cl}$ accumulation in acini of resperine-treated rats under the same conditions shown in the left panel for control acini. Data shown are derived from those shown in Figure 2 and the right panel of Figure 3.

basal rate of early $\mathrm{Cl}$ accumulation was similar to that of control cells (Fig. 4). In contrast to the latter, however, acetylcholine did not enhance the initial rate of $\mathrm{Cl}$ accumulation in cells of reserpine-treated animals (Fig. 4). However, DIDS inhibited the initial rate of $\mathrm{Cl}$ accumulation in these cells (Fig. 4), although the effect was somewhat different from that in control acini and became smaller with time (Fig. 4). In view of the effect of this inhibitor on steady state $\mathrm{Cl}$ in the cells of the treated animals (Fig. 3), the results shown in Figure 4 suggest complexities in these cells relative to either the $\mathrm{Cl}$ transport systems responsible for $\mathrm{Cl}$ accumulation or their interaction with DIDS.

Effects of furosemide. Furosemide is a loop diuretic that inhibits coupled cation/anion transport systems in epithelial cells; there is evidence that such a transport system is present in pancreatic cells (31). We therefore investigated the effect of 1 $\mathrm{mM}$ furosemide on $\mathrm{Cl}$ accumulation in the acinar preparations. In control acini, furosemide had essentially no effect when added to the cell suspensions at time zero, but reduced $\mathrm{Cl}$ accumulation significantly when added $10 \mathrm{~min}$ before addition of tracer (Fig. 5 ). Both the initial rate and the steady state accumulation were reduced in cells preincubated for this period of time with furosemide. The $\mathrm{Cl}$ content of the acini was $52 \pm 8 \mathrm{nmol} / \mathrm{mg}$ protein after $1 \mathrm{~min}$ of incubation in the presence of the inhibitor and 74 $\pm 7 \mathrm{nmol} / \mathrm{mg}$ protein after $5 \mathrm{~min}$ (Fig. 5). The steady state $\mathrm{Cl}$ accumulation was $74 \pm 6 \mathrm{nmol} / \mathrm{mg}$ protein when furosemide was present in the medium for $10 \mathrm{~min}$ before tracer (Fig. 5). All these values are significantly smaller from the corresponding ones in the absence of furosemide (Fig. 5).

Furosemide also inhibited $\mathrm{Cl}$ accumulation in unstimulated acini of reserpine-treated rats. The effect was also evident, as in control acini, in both phases of $\mathrm{Cl}$ accumulation. The $\mathrm{Cl}$ content at 1 and $5 \mathrm{~min}$ was, respectively, 28 and $46 \mathrm{nmol} / \mathrm{mg}$ protein and the steady state content was $44 \pm 3 \mathrm{nmol} / \mathrm{mg}$ protein. These were significantly reduced in relation to the corresponding values in the absence of inhibitor.

Effect of transport inhibitors on acetylcholine-stimulated acini. As shown in Table 1, DIDS and amiloride inhibited $\mathrm{Cl}$ accumulation in control acini exposed to $1 \mu \mathrm{M}$ acetylcholine. The inhibitory effect was evident in both the initial phase and the steady state phase of $\mathrm{Cl}$ accumulation (Table 1). Furosemide also inhibited $\mathrm{Cl}$ accumulation in these control cells when added 10

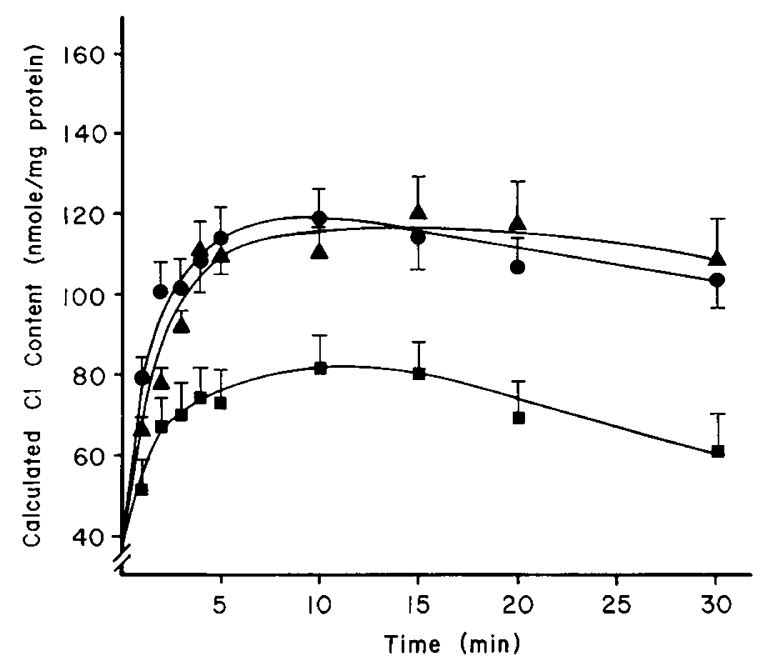

Fig. 5. Time-related changes in $\mathrm{Cl}$ content of control acini incubated in the absence (closed circles) and in the presence of $1 \mathrm{mM}$ furosemide, added to the suspensions either at time zero (triangles) or $10 \mathrm{~min}$ before tracer (squares). Data from six control experiments and from four experiments each for the two furosemide protocols.

Table 1. Effect of transport inhibitors on Cl accumulation in acetylcholine-stimulated acini

\begin{tabular}{llllcc}
\hline & & \multicolumn{4}{c}{$\begin{array}{c}\text { Cl accumulation (\% of values } \\
\text { with acetylcholine alone) }\end{array}$} \\
\cline { 5 - 6 } \cline { 4 - 6 } Inhibitor & $\begin{array}{c}\text { Type of } \\
\text { cell }\end{array}$ & $n$ & $1 \mathrm{~min}$ & $5 \mathrm{~min}$ & $10-30 \mathrm{~min}$ \\
\hline DIDS & Control & 4 & 42 & 58 & 67 \\
& Reserpine & 4 & 54 & 78 & 157 \\
Amiloride & Control & 4 & 83 & 78 & 68 \\
& Reserpine & 4 & 86 & 78 & 73 \\
Furosemide & Control & 3 & 32 & 33 & 31 \\
& Reserpine & 3 & 40 & 49 & 43 \\
\hline
\end{tabular}




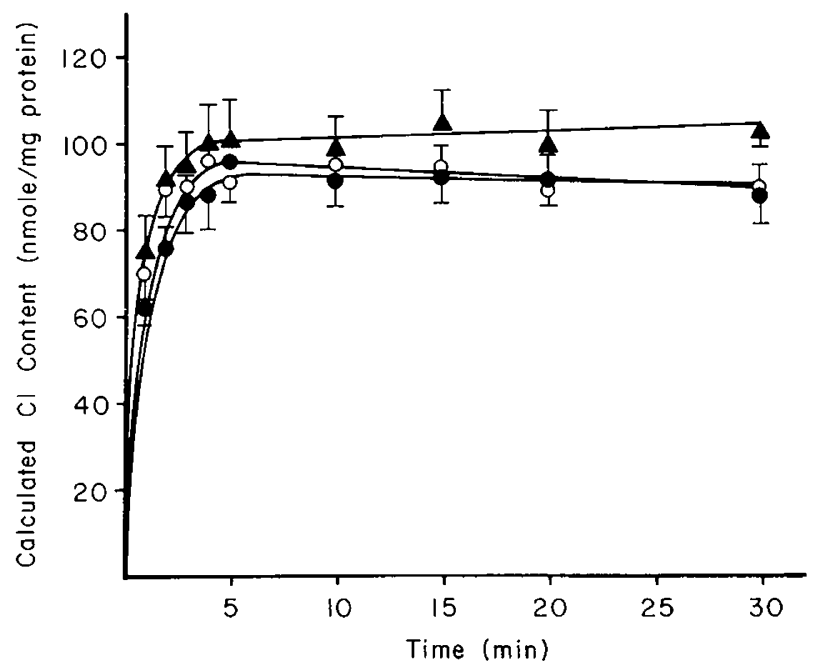

Fig. 6. Time-related changes in $\mathrm{Cl}$ content of control acini incubated in the absence (closed circles) and in the presence of either $10 \mathrm{mM}$ vasointestinal peptide (open circles) or $10 \mu \mathrm{M}$ forskolin (closed triangles). Data are from six control experiments and four each for the two test substances.

min before tracer (Table 1). As in unstimulated cells (see Fig. 3), the effect of DIDS on $\mathrm{Cl}$ accumulation by acetylcholine-stimulated acini of reserpine-treated rats was biphasic (Table 1). An initial inhibition of $\mathrm{Cl}$ accumulation was followed by a significant increase in $\mathrm{Cl}$ content, which was $157 \%$ of the corresponding value in cells not exposed to DIDS between 10 and $30 \mathrm{~min}$ of incubation (Table 1). The effect on the initial phase of accumulation was less than in control acini (Table 1). The inhibitory effect of furosemide on $\mathrm{Cl}$ accumulation was also significant in acini of reserpine-treated rats (Table 1), when the cells were exposed to this inhibitor for $10 \mathrm{~min}$ before secretagogue and tracer.

Effects of VIP and forskolin. We evaluated the effects of two other secretagogues on $\mathrm{Cl}$ accumulation in control acini. VIP acts in pancreatic epithelium through cAMP, whereas acetylcholine and caerulein use $\mathrm{Ca}^{2+}$ as their intracellular mediator (11, 14). Forskolin is a disterpene derivative that activates adenylate cyclase and cAMP formation (22).

As shown in Figure 6, neither VIP nor forskolin modified $\mathrm{Cl}$ accumulation in control acini. The initial and steady state phases of accumulation were essentially similar to those of cells not exposed to these substances.

\section{DISCUSSION}

The ion transport systems operating in pancreatic acinar cells have not been fully elucidated (14), but studies with isolated, perfused tissues (13) and with isolated cells (23) suggest that, in the rat, they include a pair of functionally linked antiports in the basolateral cell membrane that exchange $\mathrm{Na}$ for $\mathrm{H}$ and $\mathrm{Cl}$ for $\mathrm{HCO}_{3}$. The former is sensitive to amiloride and the latter to stilbene sulfonic acid derivatives such as DIDS $(24,25)$. The results of our experiments with control acini can be interpreted as lending support to this model, as these inhibitors reduced $\mathrm{Cl}$ accumulation in both resting and acetylcholine-stimulated cells. Stilbene derivatives also inhibit, however, $\mathrm{Cl}$ conductances in several epithelial and non-epithelial cells (26-29) and acetylcholine activates a $\mathrm{Cl}$ conductance pathway of fairly high permeability in pancreatic acinar cells (30). In general, the anion exchanger is sensitive to lower doses of these inhibitors (i.e. in the $\mu \mathrm{M}$ range), whereas inhibition of $\mathrm{Cl}$ conductance pathways and other ion transport systems require higher stilbene concentrations (29). Although the inhibitory effect of DIDS on $\mathrm{Cl}$ accumulation in control pancreatic acinar cells could result from blockade of the proposed $\mathrm{Cl} / \mathrm{HCO}_{3}$ antiport, it could represent equally well effects on a $\mathrm{Cl}$ conductance pathway of the high concentrations of DIDS used. Amiloride also blocks cholinergic receptors in the pancreas (31) and its inhibition of $\mathrm{Cl}$ accumulation in control acini could be due to this effect, rather than to blockade of the proposed $\mathrm{Na} / \mathrm{H}$ exchange.

Our results suggest that there are two distinct phases of $\mathrm{Cl}$ accumulation in rat pancreatic acini. The initial rate is stimulated by acetylcholine and by caerulein and is inhibited by DIDS. A steady state level of accumulation is also increased by secretagogues and is reduced to approximately the same extent by DIDS and by amiloride. The effect of amiloride on the initial rate of $\mathrm{Cl}$ accumulation is delayed but can be ascertained after 2-3 min of incubation (see Fig. 3). The steady state level attained is likely to be related to the initial rate of accumulation and the effects of the various drugs on such level could result, therefore, from their effects on this initial rate and the resulting changes in cell $\mathrm{Cl}$ concentrations, cell volume, or both.

$\mathrm{Cl}$ accumulation is altered in pancreatic acini of reserpinetreated rats, as indicated by the failure of acetylcholine to increase $\mathrm{Cl}$ accumulation and by the large and sustained accumulation of $\mathrm{Cl}$ in the continued presence of DIDS. In contrast to control acini, no significant increase in the initial rate of $\mathrm{Cl}$ accumulation was seen with acetylcholine. This suggests that reserpine administration blocks the activation by the secretagogue of the transport mechanism responsible for early $\mathrm{Cl}$ accumulation. However, both basal and acetylcholine-stimulated early accumulation of $\mathrm{Cl}$ were inhibited by DIDS in the cells of the treated animals, although to a lesser extent than in control acini. Thus, the transport mechanisms in question retain a good portion of their DIDS sensitivity but lose their acetylcholine sensitivity after reserpine administration. This suggests complex changes in the transport mechanism or mechanisms responsible for early $\mathrm{Cl}$ accumulation after chronic reserpine. As DIDS can inhibit both $\mathrm{Cl}$ conductances and $\mathrm{Cl} / \mathrm{HCO}_{3}$ exchange (see above), either or both of these mechanisms may be affected in reserpine-treated rats. Analysis of dose-related responses to DIDS will help clarify the issue further.

The sustained increase in $\mathrm{Cl}$ accumulation in the continued presence of DIDS observed in the acini of reserpine-treated animals suggests an alteration in $\mathrm{Cl}$ transport mechanisms responsible for the maintenance of steady state $\mathrm{Cl}$ content. This could result from disturbances in $\mathrm{Cl}$ exit (efflux) or from a reversal in the direction of transport by a DIDS-sensitive $\mathrm{Cl}$ / $\mathrm{HCO}_{3}$ exchange. The mechanisms of $\mathrm{Cl}$ efflux in pancreatic acini are not clear, but there is evidence that they may involve a furosemide-sensitive $\mathrm{Na}, \mathrm{K}, 2 \mathrm{Cl}$ cotransport system oriented in the opposite direction to that of salivary acini and other secretory epithelial (32). The effects of preincubation with furosemide were similar in pancreatic acini of control and reserpine-treated rats. This argues against a disturbance in $\mathrm{Cl}$ exit in the latter cells, at least by way of the cotransport mechanism. A reversal in the direction of $\mathrm{Cl} / \mathrm{HCO}_{3}$ exchange (moving $\mathrm{Cl}$ out of the cell) could occur, however, if there were changes after reserpine administration in intracellular $\mathrm{HCO}_{3}, \mathrm{Cl}$, or $\mathrm{H}(\mathrm{pH})$ concentrations or in metabolic functions critical for anion transport. Clearly, additional studies are necessary to explore these questions.

$\mathrm{Cl}$ accumulation was enhanced in control acini by secretagogues that use $\mathrm{Ca}^{2+}$ as their intracellular mediator, but not by those that act through cAMP (14). As previous evidence indicated that $\mathrm{Cl}$ accumulation in pancreatic acini is dependent on the presence of $\mathrm{Ca}^{2+}$ in the incubation medium (33), it is possible that the alterations in $\mathrm{Cl}$ accumulation in acini of reserpinetreated rats is the result of a disturbance in the mediator role of $\mathrm{Ca}^{2+}$. This requires further study, but the alteration in $\mathrm{Cl}$ accumulation observed in this study can explain the reduced fluid secretion observed in vivo in reserpine-treated rats $(4,7,8)$, as $\mathrm{Cl}$ is required for secretagogue-induced fluid secretion in the rat (12). Transcellular $\mathrm{Cl}$ transport is thought to be important also in human pancreatic acini (34) and alterations in pancreatic fluid 
and anion secretion are prominent in $\mathrm{CF}$ (35). It is possible, therefore that these alterations are related to abnormal $\mathrm{Cl}$ transport in pancreatic acini of affected individuals, perhaps similar to those observed in this study on an experimental animal model of this disease.

The $\mathrm{Cl}$ transport defect in sweat glands (36) and airways (17, 18) of CF patients seems to be related, however, to a disturbance in a cAMP-mediated pathway regulating $\mathrm{Cl}$ transport. As $\mathrm{Cl}$ transport appears to be regulated by $\mathrm{Ca}^{2+}$, rather than by cAMP, in rat salivary (37) and pancreatic acinar cells (33), a question arises about the relevance of the findings of this and the previous study on salivary cells of the reserpinized rat model. Ion channels and conductances are variously regulated by $\mathrm{Ca}^{2+}$ or by cAMP in exocrine and nonexocrine tissues (38) and one can speculate that the disturbance of $\mathrm{Cl}$ transport in exocrine glands of $\mathrm{CF}$ patients and of the reserpine rat model may be due to a regulatory malfunction by either of these intracellular messengers in accordance with the tissue involved. This may involve the interaction between membrane transport proteins and regulatory molecules activated by either $\mathrm{Ca}^{2+}$ or cAMP. Studies on the regulation of $\mathrm{Cl}$ transport in human salivary and pancreatic cells are clearly necessary to establish the validity of this speculation.

\section{REFERENCES}

1. Martinez JR, Barbero GJ (eds) 1985 Animal Models for Cystic Fibrosis: The Reserpine-Treated Rat. San Francisco Press, San Francisco

2. Martinez JR, Adelstein E, Quissell DO, Barbero GJ 1975 The chronically reserpinized rat as a possible model for cystic fibrosis: I. Submaxillary gland morphology and ultrastructure. Pediatr Res 9:463-469

3. Martinez JR, Adshead PC, Quissell DO, Barbero GJ 1975 The chronically reserpinized rat as a possible model for cystic fibrosis: II. Composition and cilioinhibitory effects of submaxillary saliva. Pediatr Res 9:470-475

4. Perlmutter J, Martinez JR 1978 The chronically reserpinized rat as a possible model for cystic fibrosis: VII. Alterations in the secretory response to secretin and to cholecystokinin from the pancreas in vivo. Pediatr Res 12:188-194

5. Setser ME, Spicer SS, Simson JAV, Martinez JR 1979 Altered granule discharge and amylase secretion of parotid glands in reserpine-treated rats. Lab Invest 41:256-264

6. Setser ME, Spicer SS, Simson JAV, Adamson M, Martinez JR 1979 The effects of reserpine on the ultrastructure and secretory responses of rat exocrine pancreas. Exp Mol Pathol 31:413-422

7. Morton D, Parker A, Estrada P, Martinez JR 1980 Exocrine pancreatic secretion in rats treated with reserpine after stimulation with pilocarpine, dopamine and caerulein. Pediatr Res 14:18-20

8. McCurdy RE, Martinez JR 1981 The chronically reserpinized rat as a model for cystic fibrosis: alterations in pancreatic enzyme secretion and storage. Pediatr Res 15:1308-1313

9. Mawhinney TP, Feather MS, Martinez JR, Barbero GJ 1979 The chronically reserpinized rat as an animal model for cystic fibrosis: I. Acute effect of isoproterenol and pilocarpine upon pulmonary lavage fluid. Pediatr Res 13:760-763

10. Mawhinney TP, Martinez JR, Feather MS, Barbero GJ 1980 Composition of pulmonary lavage fluid in control and reserpine treated rats following chronic isoproterenol and pilocarpine administration. Pediatr Res 14:872-875

11. Gardner JD, Jensen RF 1986 Receptors and cell activation associated with pancreatic enzyme secretion. Annu Rev Physiol 48:103-118

12. Petersen $\mathrm{OH}$, Ueda $\mathrm{N} 1977$ Secretion of fluid and amylase in the perfused rat pancreas. J Physiol (Lond) 264:819-835

13. Seow KTF, Lingard JM, Young JA 1986 Anionic basis of fluid secretion by rat pancreatic acini in vitro. Am J Physiol 250:G140-G148

14. Hootman SR, Williams JA 1987 Stimulus secretion coupling in the pancreatic acinus. In: Johnson LR (ed) Physiology of the Gastrointestinal Tract, 2nd ed, Vol 2. Raven Press, New York, pp 1129-1146

15. Petersen OH, Maruyama Y 1984 Calcium activated potassium channels and their role in secretion. Nature 307:693-696

16. Quinton PM 1983 Chloride impermeability in cystic fibrosis. Nature 301:421422

17. Welsh MJ, Liedtke CM 1986 Chloride and potassium channels in cystic fibrosis airway epithelia. Nature 322;467-470

18. Frizzell RA, Rechkemmer G, Shoemaker RL 1986 Altered regulation of airway epithelial cell chloride channels in cystic fibrosis. Science 233:558-560

19. Martinez JR, Cassity N 1985 The chronically reserpinized rat as a model for cystic fibrosis: Abnormal $\mathrm{Cl}^{-}$transport as the basis for reduced salivary fluid secretion. Pediatr Res 19:711-716

20. Martinez JR, Quinton PM 1985 Apparent decrease in $\mathrm{Cl}$ permeability in reserpinized rats. CF Club Abstracts, XXVI Annual Meeting, p 13(abstr)

21. Lowry OH, Rosebrough NF, Farrar AL, Randall RJ 1951 Protein measurement with the Folin phenol reagent. J Biol Chem 193:265-268

22. Seamon KB, Daly JW, Metzger H, DeSouza NJ, Reden J 1981 Forskolinunique diterpene activator of adenylate cyclase in membranes and in intact cells. Proc Natl Acad Sci USA 78:3363-3367

23. Hellmessen W, Christian AL, Fasold H, Schulz I 1985 Coupled $\mathrm{Na}^{+}-\mathrm{H}^{+}$ exchange in isolated acinar cells from rat exocrine pancreas. Am J Physiol 249:G125-G136

24. Cabantchik ZI, Knauf PA, Rothstein A 1978 The anion transport system of the red blood cell. The role of membrane protein evaluated by the use of probes. Biochim Biophys Acta 515:239-302

25. Benos DJ 1982 Amiloride: a molecular probe of sodium transport in tissues and cells. Am J Physiol 242:C131-C145

26. Inoue I 1985 Voltage dependent chloride conductance in the squid giant axon membrane and its blockage by some disulfonic stilbene derivatives. J Gen Physiol 85:519-538

27. Kimmich GA, Montrose M 1985 A SITS-sensitive chloride conductance pathway in chick intestinal cells. Fed Proc 44:1743(abstr)

28. Nelson DJ, Tang JM, Palmer LG 1984 Single channel recordings of apical membrane chloride conductance in A6 epithelial cells. J Memb Biol 80:8189

29. Montrose M, Randles J, Kimmich GA 1987 SITS-sensitive $\mathrm{Cl}^{-}$conductance pathway in chick intestinal cells. Am J Physiol 253:C693-C699

30. Petersen OH, Philpott HG 1980 Mouse pancreatic acinar cells: the anion selectivity of the acetylcholine-opened chloride pathway. J Physiol (Lond) 306:481-492

31. Kuipjers GAT, dePont JJHHM, van Nooy IGP, Fleuren-Jakobs AMM, Bonting SL, Rodrigues de Miranda JF 1984 Amiloride is a cholinergic antagonist in the rabbit pancreas. Biochim Biophys Acta 804:237-244

32. Petersen OH, Singh J 1985 Acetylcholine-evoked potassium release in the mouse pancreas. J Physiol (Lond) 365:319-329

33. Putney JW Jr, Van de Walle CM 1980 Role of calcium in stimulation of ${ }^{36} \mathrm{Cl}$ uptake by dispersed pancreatic acinar cells. Biochem Biophys Res Commun 95:1461-1466

34. Petersen OH, Findlay I Iwatsuki N, Singh J, Gallacher DV, Fuller CM, Pearson GT, Dunne MJ, Morris AP 1985 Human pancreatic acinar cells: studies of stimulus-secretion coupling. Gastroenterology 89:109-117

35. Kopelman H, Durie P, Gaskin K, Zvi Weizman CB, Forstner G 1985 Pancreatic fluid secretion and protein hyperconcentration in cystic fibrosis. $\mathrm{N}$ Engl J Med 312:329-334

36. Sato K, Sato F 1984 Defective $\beta$ adrenergic response of cystic fibrosis sweat glands in vivo and in vitro. J Clin Invest 73:1763-1771

37. Martinez JR, Cassity $\mathrm{N} 1986{ }^{36} \mathrm{Cl}$ fluxes in dispersed rat submandibular acini: Effects of $\mathrm{Ca}^{2+}$ omission and of the ionophore. A23187. Pflügers Arch 407:615-619

38. Levitan IB 1985 Phosphorylation of ion channels. J Memb Biol 87:177-190 